http://dx.doi.org/10.4322/pmd.2013.014

\title{
New product development in brazilian technology-based small and medium enterprises
}

\author{
José Carlos de Toledo", Glauco Henrique de Sousa Mendes", Daniel Jugend ${ }^{b}$, Sérgio Luís da Silva ${ }^{a}$ \\ Universidade Federal de São Carlos \\ Universidade Estadual Paulista \\ e-mails: toledo@ufscar.br; glauco@dep.ufscar.br; danie|@feb.unesp.br; sergio|@ufscar.br
}

\begin{abstract}
This article examines new product development (NPD) in small and medium-sized Brazilian enterprises (SMEs) in two technology-based industries: medical devices and process control automation devices. A conceptual model that categorizes factors that contribute to the success of a new product was established. The data were collected from a sample of 62 Brazilian SMEs. The conceptual model was tested to examine the relationships between NPD practices and new product success. Data analysis reveals that new product success in medical device companies is related to organizational characteristics such as NPD proficiency and marketing skills; while in process control automation device companies, they deal in a large degree with product differentiation, innovation and capability to analyze the targeted market. Due to the relatively small sample size, caution should be exercised when interpreting the results.
\end{abstract}

Keywords: new product development, success critical factors, small and medium enterprises, medical device industry, process control automation device industry.

\section{Introduction}

A traditional research line in New Product Development (NPD) is to identify critical success factors. Many authors have studied cases of successful and failed projects in order to identify practices that could improve NPD (COOPER; KLEINSCHIMIDT, 1995; SONG; SOUDER; DYER, 1997; POOLTON; BARCKLAY, 1998; ERNEST, 2002; KAHN; BARCZAK; MOSS, 2006).

Most of theses studies have concentrated in large companies. However, the reality of most small and medium companies is somewhat different as far as organizational structure, scope of technological development and manufacturing and production capacity are concerned (LEDWITH; O'DWYER, 2009).

Innovative small and medium-sized Enterprises (SMEs) make a significant contribution in the global economy, with respect to enterprise development and new job creation. There also is an increasingly important role for SMEs to contribute to economic growth and technological development specifically in those developing countries where liberalization and globalization of the economy is currently taking place.

The NPD practices adopted by Brazilian Small and Medium Enterprises (SMEs) in technology-based industries are little understood. The Technology-based Companies are associated with products with high technology products.
In the case of developing countries, they play an important role in import substitution and in creating networks of local companies with higher technological content. This paper relates an industry-specific study in order to better understand NPD practices adopted during the execution of NPD projects and their impact on the outcome of the new product.

The objective of this paper is to identify and analyze management practices which influence the success of NPD projects, based on data collected in a sample of 62 Brazilian SMEs. The research focused on two of the most relevant industries in the country: medical device industry (MD) and process control automation device industry (PCAD).

These two industries are outstanding on account of their technological dynamism. According to the taxonomy of the Organization for Economic Cooperation and Development (OECD), MD and PCAD are considered high technology based in Brazil. This sort of company can be classified as based on science or specialized supplier (BELL; PAVITT, 1993)

The paper is organized as follows: following this introduction the relevant studies from the literature are reviewed in the second section. Research method is reported in the third section, followed by data analysis and results in the fourth section. In the fifth section the results are discussed and implications are explored. At last, limitation and possible future works are presented. 


\section{Critical success factors in NPD management}

Critical success factors associated with product development are tactics or methods that, when well executed, can contribute to increase the likelihood of new product success. Several studies about the influence of NPD practices on product success were taken as reference (MONTOYA-WEISS; CALANTONE, 1994; COOPER; KLEINSCHMIDT, 1995; GRIFFIN, 1997; SONG; SOUDER; DYER, 1997; SOUDER; BUISSON; GARRET, 1997; POOLTON; BARCLAY, 1998; ERNST, 2002; MARCH-CHORDA; GUNASEKARAN; BEGOÑA, 2002; COOPER; EDGETT; KLEINSCHMIDT, 2004a, b, c; SONG; NOH, 2006; KAHN; BARCZAK; MOSS, 2006; LEDWITH; O'DWYER, 2009)

Figure 1 shows the conceptual model adopted by the present study. The dependent variable of the conceptual model is the perceived commercial success of new product. The independent variables used, drawn from the examination of the NPD bibliography, were: new product innovation degree, marketing skills, product advantage, technology sources, company's skills, project leader's skills, cross-functional integration, project team organization, NPD process proficiency and NPD-related activity proficiency. These factors are supposed to contribute to the success of a new product.

\subsection{New product innovation degree}

The new product innovation degree refers to the amount of technological change in relation to the technology incorporated in existing products. There is a strong association between companies' innovation tendency and

CONSTRUCTS

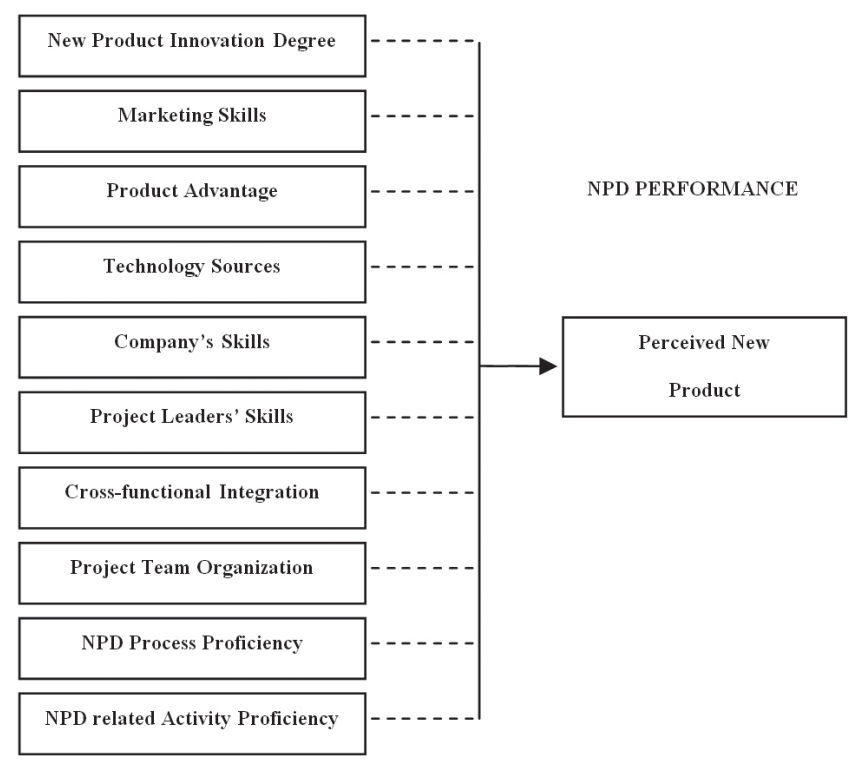

Figure 1. The conceptual model of research. their growth in market-share (HART, 1993). However, no consensus exists regarding the relationship between product innovation degree and its success (GARCIA; CALANTONE, 2002). Nevertheless, Mosey (2005) found that SMEs' flexibility and ability to adapt offers them a competitive advantage over their larger rivals, arguing that SMEs can compete with their larger rivals by developing new-to-market products using novel technologies.

\subsection{Marketing skills}

Marketing skills include aspects such as company's capacity to assess the new product market potential, to understand the target-market needs and to translate that information into product specifications. A strong market orientation is a critical success factor for new product success (COOPER; KLEINSCHMIDT, 1995; SONG; SOUDER; DYER, 1997; LANGERAK; HULTINK; ROBBEN, 2004). Verhees and Meulenberg (2004) found that market orientation was useful in the selection of an attractive product assortment; it also increased customer market intelligence, which is related positively to performance in small firms.

Market characteristics also influence new product success (SOUDER; BUISSON; GARRET, 1997; ERNST, 2002; LANGERAK; HULTINK; ROBBEN, 2004). Maturity of the market, the potential for market growth, changes in the customer's perceptions and market uncertainty are viewed as uncontrollable factors derived from contingent environment conditions, but the company can be kept aware about these conditions if it has marketing skills (YAP; SOUDER, 1994).

\subsection{Product advantage}

The existence of a new product strategy has long been recognized as a core requirement in the NPD (ERNST, 2002). The existence of such a strategy is an important indicator of product advantage in SMEs. In the same way, the relationship between the new product and the company's strategies have been found to correlate with NPD success (COOPER; KLEINSCHIMIDT, 1987; SONG; NOH, 2006).

Product advantage refers to customer's perception of product superiority with respect to quality, cost, unique attributes and superior performance in relation to competitors' products. It is one of the most frequently reported strategic factor in the NPD studies (MONTOYAWEISS; CALANTONE, 1994). Many authors also identify product characteristics that lead them to success (YAP; SOUDER, 1994; POOLTON; BARCKLAY, 1998).

\subsection{Technology sources}

The objective of the technological strategy is to obtain, develop and apply technology as a competitive advantage factor. The technological strategy should make explicit the 
position of the company as a technology leader or follower, the key technologies for the future development of the company and the technology sources.

The sources of technology contribute for the success or failure of a new project because they vary in the capabilities they require from the companies for acquisition, adaptation and management of technical knowledge and integration of know-how and personnel (SCOTT, 2000).

New technologies can be generated in-house during $R \& D$ activities or they can be obtained from external sources, as for example the acquisition of capital goods, software and services, the access to open sources of technology and the development of new technologies in partnership with other organizations (ORGANIZATION..., 1997).

\subsection{Company skills}

Company skills have been associated to NPD success (COOPER; KLEINSCHIMIDT, 1987; SONG; SOUDER; DYER, 1997; SONG; NOH, 2006). They are distinctive capabilities of personnel or organizational functions that increase the NPD performance. They can be defined as the competency and capacity to accurately execute activities interfering directly in the NPD proficiency. They are often significant areas of weakness within small technologybased companies, where entrepreneurs tend to emphasize the technological side of their business and neglect other company skills (BERRY; TAGGART, 1998).

\subsection{Project leader skills}

One of the most important factors that affect NPD performance is the project leader (BROWN; EISENHARDT, 1995). The project leaders facilitate communication between the project team and senior management and they also hold the responsibility of keeping the team members motivated and focused in their work (THIEME; SONG; SHIN, 2003).

The technical, managerial and personal skills of the project leaders affect the success of the new product project. Power, vision, and management skills are posited as the central characteristics of the project leader, who should also have enough authority delegated by top management to lead the new product project towards success (BROWN; EISENHARDT, 1995; SCHWEIGER; ATAMER; CALORI, 2003).

The project leaders differ from other leaders. They need to lead under uncertain conditions, exhibiting creativeness and persistence in innovation processes, skills to cooperate and integrate people with different specialization backgrounds and behavioral patterns (KIM; BYUNGWOOK; JONGSEOK, 1999).

\subsection{Cross-functional integration}

Cross-functional integration are very important for NPD success (GRIFFIN, 1997; SOUDER; BUISSON;
GARRET, 1997; HAQUE; KULWANT; BARSON, 2000; MARCH-CHORDA; GUNASEKARAN; BEGOÑA, 2002; COOPER; EDGETT; KLEINSCHMIDT, 2004a; SONG; $\mathrm{NOH}, 2006$ ).

The SMEs possess considerable potential advantages over large firms in that they have less organizational rigidities. This results in an ability to facilitate effectively information and communication flows within the organization and to respond quickly to market. Indeed, the small firms operating in high-tech industries tend to have entrepreneurial management styles and structures which are characterised by informal control mechanisms, adaptability, flexibility and open communication channels (BERRY; TAGGART, 1998).

\subsection{Project team organization}

There are four predominant forms of project team organization: functional team structure, light-weight structure, heavy-weight structure and autonomous teams (CLARK; WHEELWRIGHT, 1993). The benefits of adopting a more organic structure (matrix and per project or autonomous teams) have been widely propagated (LARSON; GOBELLI, 1988). The use of more organic structures requires managerial skills to form and prepare multifunctional teams; otherwise the risk exists of substituting a greater number of problems for the integration benefits (RIEK, 2001).

Studies have indicated a contingent approach, to adequate the organizational structure of each project to the company's cultural characteristics: a functional-based form of structure is effective for routine and non-radical projects while a more organic structure is appropriate for more unusual and radical projects (LEE; LEE; SOUDER, 2000).

\subsection{NPD process proficiency}

Many studies about NPD success have shown that proficiency in development activities brings positive impacts to new product performance (COOPER; KLEINSCHIMIDT, 1987; CLARK; FUJIMOTO, 1991; BROWN; EISENHARDT, 1995; COOPER; EDGETT; KLEINSCHMIDT, 2004c).

Although it is necessary to guarantee the quality of execution of all NDP activities, some activities have a greater impact in cost and time of development of the projects, as well as in the quality of the product. Some authors highlight the importance of pre-development activities (ATUAHENE-GIMA, 1996; ERNST, 2002; KAHN; BARCZAK; MOSS, 2006). Attention must be given to pre-development activities, mainly conducting studies involving technical issues, market and viability analysis.

Besides those activities that directly pertain to NPD process, other activities also contribute to new product success, such as goal setting for the project, procedures for follow-up and evaluation of new project 
performance, monitoring of legislation, and documentation for the homologation of the product (COOPER; EDGETT; KLEINSCHMIDT, 2004b, c).

\section{Research method}

\subsection{Sample of companies and projects}

The research reported is a survey of a sample of 62 Brazilian small and medium-sized enterprises operating in two industries: medical devices and process control automation devices. Enterprises size was classified in terms of employment levels, in line with the definition of SMEs adopted by Brazilian laws. Small firms were defined as those having fewer than 50 employees and medium firms were defined as those having fewer than 500 employees.

A contact via e-mail or phone was made to confirm that the selected companies fit the criteria adopted: small or medium companies, which had new product development activity and had completed projects and launched new products in the last five years. The researchers interviewed face to face the person responsible for the projects under analysis, usually the project leader. The objective was to examine two new product projects in each company, one being a success and the other a failure (Table 1). All the answers were supposed to be grounded on the history, facts and situations experienced at the time of the project execution, so the interviewees were screened for knowledge and responsibility of the project at that time.

\subsection{Research instrument}

The questionnaire used for data collection was structured to identify the practices adopted during the execution of projects of new devices. It was tested in four companies before being employed in the survey, to ensure the clear understanding of the terms and contents of the questions and that the scales adopted were appropriate.

The questionnaire considered ten constructs describing possible NPD factors affecting project success: new product innovation degree, marketing skills, product advantage, technology sources, company skills, project leader skills, cross-functional integration, project team organization, NPD process proficiency and NDP related activities proficiency. The construct representing the dependent variable was the perceived of product performance.

Table 1. Synthesizes the sample related data.

\begin{tabular}{|l|c|c|c|c|}
\hline Industries & SMEs & $\begin{array}{c}\text { Successful } \\
\text { projects }\end{array}$ & $\begin{array}{c}\text { Failed } \\
\text { projects }\end{array}$ & $\begin{array}{c}\text { Projects } \\
\text { total }\end{array}$ \\
\hline PCAD & 32 & 32 & 23 & 55 \\
\hline MD & 30 & 30 & 19 & 49 \\
\hline Total & 62 & 62 & 42 & 104 \\
\hline
\end{tabular}

Each construct is comprised by a set of individual variables (factors) identified and defined in the bibliographical review. Construct reliabilities (Cronbach`s alpha) were calculated and exceeded 0.70, which is considered acceptable.

The individual variables were presented in the questionnaire in the form of statements about the existence of a given practice and the interviewees expressed their perception about the degree in which the practice adopted in the project agreed with the statement. The classification of a new product project in either success or failure followed a 5 points Likert scale. Products given 1 or 2 points (well below expectations or below expectations) were classified as failure, while those reaching 3 (as expected), 4 (above expectations) or 5 (well above expectations) were taken as successful projects.

\subsection{Statistical analyses}

In quantitative survey utilizing qualitative variables measured in Likert scale, it is recommended to use statistical techniques that will provide the correlation degree between dependent and independent variables, the significance analysis of the observed correlation coefficients ( $p$ test), as well as the Main Components Analysis (HAIR et al., 1998).

In order to measure the correlation between each individual variable and outcome of the product, the Spearman correlation coefficient, which indicates the dependency level between two ordinal variables, was calculated. Coefficients greater than 0.50 were considered strong positive correlation while those between 0.30 and 0.49 were considered as moderate positive correlation. Below 0.30 there is evidence of weak statistical correlation or no dependency between the variable and the outcome of a new product.

Confidence level tests (p-value) were calculated to observe the degree of such relations. Correlations which had p-values greater than $95 \%$ were considered positive, while values below $95 \%$ confidence level were considered to have no correlation. The existence of significant differences between the answers of successful and failed projects was calculated using the Mann-Whitney test. The levels of significance for the differences between averages were also calculated.

The relevance of each individual variable was defined by the existence of significant differences in the Mann-Whitney test, by the analysis of Spearman correlation coefficient and by the level of significance of the correlation $(p \leq 0.05)$.

The individual variables were then reduced by Factor Analysis, that is: the multi-item construct (main component) fitted into one factor which explained a percentage of the total variance of this construct. The correlation between the main components and the outcome of new products was calculated. From the statistical procedures adopted and the interpretation of the results, it was possible to identify a set of variables (practices) that affect the success of new products in these companies. 


\section{Analyses of results}

\subsection{Individual variables analysis}

The interviewee classified the product as successful or not by comparison between the pre-launching expectations and the performance of the product in the market (Table 2).

The variables were considered statistically significant when the Spearman correlation coefficient was greater than 0.30 and $p$-value was below 0.05 . The variables that revealed to be significant just for companies in the MD industry were the following:

- Project resulted in a platform product $(\mathrm{r}=0.41)$;

- Growing market for the new product $(\mathrm{r}=0.35)$;

- Project leader's capability to motivate development team $(\mathrm{r}=0.47)$;

Leadership style facilitated communication and conflict resolution $(\mathrm{r}=0.35)$;

- Development team was motivated $(r=0.32)$;

- Participation of different functional areas in the origin and screening of ideas $(\mathrm{r}=0.54)$;

- Quality of execution of technical development ( $\mathrm{r}=0.41)$;

- Quality of documentation related to the project $(\mathrm{r}=0.38)$;

- Fulfillment of the legal requirements related to the product $(\mathrm{r}=0.41)$.

The variables that indicated to be relevant just for the PCAD companies were the following:

- Project turned into a derivative product $(r=0.36)$;

- Synergy between market and the new product $(\mathrm{r}=0.40)$

- Cost advantage compared to competitors' products $(\mathrm{r}=0.42)$;

- Integration with company's competitive and product strategies $(r=0.35)$;

- Participation of development team in decisions about the project $(\mathrm{r}=0.30)$;

- Participation of various areas in launching of product $(\mathrm{r}=0.41)$

- Quality of launching activities $(r=0.44)$.

The divergence observed in the two industries studied may be explained by the characteristics of each industry. The MD companies develop products which will be mass-produced, destined to clients such as hospitals and clinics which use and demand certain functionalities, but do not know the technical aspects incorporated into the products. A success platform product allows companies to expand the product line that they can offer to their clients. Another characteristic is that medical devices need to be validated by governmental control and certification agencies which demand from those companies great attention to the mandatory documentation and fulfillment of legal requirements to comply with domestic or international legal standards. On the other hand, for PCAD companies, the adoption of certification (e.g. ISO 9001 certification) is not mandatory and could be a company's choice or it could be demanded by a client.

PCAD products are normally customized to each industrial customer. The new product will be incorporated into that customer's process and generally the customer is familiar with the product or service being purchased. In the PCAD industry, product approval lies with the industrial customer who uses the product and assesses its efficiency, reliability and maintainability. These characteristics explain the importance of critical success factor such as: derivative products, synergy between markets already explored by the companies and the new product and the necessity of quality in the launching activities.

Table 3 shows the variables that are statistically significant in both industries.

The first three variables in Table 3 refer to the companies' capability to survey customers' needs, translate them into requirements and, finally, into product measurable specifications. The assessment of the market potential for the new product showed a moderate correlation with the success of the new product. This variable represents the companies' skill to collect, organize and analyze different sources of market information.

Although the implementation of this practice was not researched in this survey, it is observed that successful projects are characterized by the new products effectiveness to meet customers' expectations and needs, whether industrial customers (PCAD) or specialized professionals such as doctors and other health care professionals (MD). To involve the end user or customer in NPD is important to ensure that the product fulfils his needs, so increasing the likelihood that the product will turn to be a market success.

Two variables in the product advantage construct: technical performance superior to competitors' and

Table 2. Correlation between outcome evaluation criteria and new product success.

\begin{tabular}{|l|c|c|c|c|}
\hline \multicolumn{1}{|c|}{ Construct and criteria } & \multicolumn{1}{|c|}{ PCAD } & \multicolumn{2}{c|}{ MD } \\
\hline $\begin{array}{l}\text { New product outcome } \\
\text { (success or failure) }\end{array}$ & Correlation coefficient & p-value & Correlation coefficient & \\
\hline New product overall return & $0.696^{*}$ & 0.000 & $0.707 *$ & 0.000 \\
\hline
\end{tabular}

*Significance level $\mathrm{p} \leq 0.001$. 
integration with company's products and competitive strategies were shown to influence product success and, therefore, to deserve careful attention in project management.

The findings indicate the importance of the leader as a critical success factor. As the person in charge of organizing and directing the development team, he has an essential role in guiding the process of development of the new product in companies of both industries, and he must have good managerial, technical and interpersonal skills.

Two variables related to the NPD process proficiency showed positive correlation to product result: origin and screening of ideas, and technical and economic viability analysis. They were indicated as success factors, although with different intensity between industries.

The earlier stages of the NPD process associated to product advantage have a positive effect on new product success. These findings allow us to assume that predevelopment activities should be carefully managed in NPD process by such companies, for that is phase when the characteristics desired by customers are translated into specifications. Also the company's strategic vision is incorporated in the NPD process.

\subsection{Main components analysis}

Table 4 shows the ten constructs (main components) and the respective correlation coefficients, $p$-values and the explained variances pertaining to each construct

These findings confirm the analysis of individual variables. Possibly as a function of the type of market it serves, that is, customized products for industrial customers, the priority for PCAD companies is to offer innovative products with characteristics that stand out. Therefore, attention to the technical and economic requirements of the product and the comprehension of customers' specific needs are crucial. The translation of technical and economic requirements into the derived specifications depends upon the project leader's skills.

Success in MD companies depends more heavily on company's organizational characteristics, such as quality

Table 3. Test results: common individual variable for both industries.

\begin{tabular}{|l|c|c|}
\hline \multicolumn{1}{|c|}{ Constructs and variables } & PCAD & MD \\
\cline { 2 - 3 } & Correlation coefficient & Correlation coefficient \\
\hline Marketing skills & & \\
\hline Correct identification of market potential & $0.34(\mathrm{p}=0.015)$ & $0.45(\mathrm{p}=0.002)$ \\
\hline Consumers' expectations about the new product & $0.36(\mathrm{p}=0.012)$ & $0.44(\mathrm{p}=0.002)$ \\
\hline Capability to translate expectations into specifications & $0.57(\mathrm{p}=0.000)$ & $0.61(\mathrm{p}=0.000)$ \\
\hline Product advantage & & $0.46(\mathrm{p}=0.002)$ \\
\hline Technical performance superior to competitors' & $0.41(\mathrm{p}=0.003)$ & $0.44(\mathrm{p}=0.003)$ \\
\hline Integration with company's products and competitive strategies & $0.35(\mathrm{p}=0.014)$ & \\
\hline Project leader's skills & & $0.35(\mathrm{p}=0.019)$ \\
\hline Interpersonal skills necessary for project. & $0.35(\mathrm{p}=0.012)$ & \\
\hline NPD process proficiency & & $0.51(\mathrm{p}=0.000)$ \\
\hline generation and screening of ideas & $0.32(\mathrm{p}=0.022)$ & $0.40(\mathrm{p}=0.005)$ \\
\hline technical and economic viability analysis & $0.48(\mathrm{p}=0.000)$ & \\
\hline
\end{tabular}

Table 4. Test results: construct level.

\begin{tabular}{|l|c|c|c|c|c|c|}
\hline \multirow{2}{*}{$\begin{array}{c}\text { Main } \\
\text { components }\end{array}$} & \multicolumn{3}{c|}{ PCAD } & \multicolumn{3}{c|}{ MD } \\
\cline { 2 - 7 } & $\begin{array}{c}\text { Correlation } \\
\text { coefficient }\end{array}$ & p-value & $\begin{array}{c}\text { Explained } \\
\text { variance* }\end{array}$ & $\begin{array}{c}\text { Correlation } \\
\text { coefficient }\end{array}$ & $\begin{array}{c}\text { p-value } \\
\text { variance* }\end{array}$ \\
\hline New Product innovation degree & 0.538 & 0.000 & 0.450 & 0.441 & 0.002 & 0.460 \\
\hline Marketing skills & 0.390 & 0.003 & 0.503 & 0.592 & 0.000 & 0.442 \\
\hline Product Advantage & 0.447 & 0.001 & 0.483 & 0.449 & 0.001 & 0.479 \\
\hline Technology sources & 0.098 & 0.475 & 0.320 & 0.055 & 0.709 & 0.320 \\
\hline Company's skills & 0.201 & 0.141 & 0.760 & 0.143 & 0.328 & 0.490 \\
\hline Project leader's skills & 0.408 & 0.002 & 0.687 & 0.489 & 0.000 & 0.519 \\
\hline Cross-functional integration & 0.306 & 0.023 & 0.402 & 0.530 & 0.000 & 0.270 \\
\hline Project team organization & 0.162 & 0.237 & 0.485 & 0.097 & 0.503 & 0.508 \\
\hline NPD process proficiency & 0.398 & 0.003 & 0.330 & 0.612 & 0.000 & 0.483 \\
\hline
\end{tabular}

* explained variance in the construct. 
of NPD and marketing skills. In successful projects, market assessments were properly carried out and users' requirements were correctly translated into product specifications. In these companies, the quality of execution of NPD activities differentiates successful projects from unsuccessful ones, mainly in pre-development activities (generation and screening of ideas, concept formulation and viability analysis).

Cross-functional integration, as a construct, proved to be a critical success factor, mainly to MD companies. The involvement of functional areas (Production and Commercial) in NPD should be stimulated, mainly in the pre-development phase. This phase has significant impact on cost, quality and development time indicators. PCAD companies did not show the same behavior, since that construct proved to be a less discriminating factor to success, because successful projects as well as failed ones presented a higher grade for this factor, indicating that functional integration tends to be more consolidated in these companies.

Project leader's skills also presented new product success correlation in both industries (Table 4). The project leader function is essential to steer the new product development, since he is directly responsible for the organization and management of the development team members.

It can be stated that there are no statistical evidence of correlation between company skills levels and new product success. Possibly due to the fact that the companies surveyed are small, the project leader's skills fulfill the company skills role.

The factors sources of technology and organization of project teams have no influence on the success or failure of the products developed by the companies in both industries studied. The small and medium size of the companies may influence in the use of predominantly informal and intra firm mechanisms for the development new technologies. In the same way, a lean and informal organizational structure, the team organization models didn't influence the outcome of the products developed. Probably that is due to the ease with which satisfactory levels of communication and collaboration inter-areas can be reached and also to the adequate choice of project leaders.

\section{Conclusions}

The findings presented have some interesting implications for the managers of small firms about their view of new product success. The conceptual model incorporates a set of factors deemed critical for NPD success. The interpretation of the results allowed the identification of possible priorities and items that deserve special attention of researchers and managers in NPD process.

The constructs associated to new product results are not the same in the two industries. Thus, PCAD companies appear to be more product-oriented, while MD companies appear to be more oriented towards development process.

This study confirm a proposition widely cited in NPD management manuals: that new product projects should be oriented to the targeted market. Pre-development should be carefully managed in NPD in companies of both industries, because activities involving knowledge of market characteristics, idea generation and selection, and viability analysis play an important role in the success of the new product. Successful projects in SMEs tend to be those in which market assessment was properly carried out and users' requirements were correctly translated into new product specifications.

The adequate involvement of functional areas at the predevelopment stage would contribute to a more rational use of resources in product development as well as to reduce the project rework rate. The small size of these companies may turn out to be an advantage, since it allows a greater integration of functional areas.

Companies in both industries should envision product development as a wide scope business process that justifies special treatment to the coordination of the involvement of customers, suppliers and all the company's functional areas.

Companies should also invest in improving project leaders' managerial and relationship skills, because it affects the performance of all the people involved in new product development. The statistical analyses show moderate correlation coefficients as regards the many variables related to project leaders. However, the importance of the project leader in running successful projects was made clear in the interviews.

The results do not match exactly the success factors described in the NPD bibliography. As Technology-based companies, it was expected that acquisition and technology transfer processes would be important to the success of their projects, as pointed by some authors (SOUDER; BUISSON; GARRET, 1997; SCOTT, 2000). This hypothesis was not proven by the results of this research, since the sample companies hardly utilize mechanisms for acquisition of external technology. Technologies are developed internally and companies acquire at low cost from mass-producers those systems and components that they do not produce, such as electronic components.

Another construct not significant is the relationship between the organizational arrangement of the project team and the new product outcome. The functional approach is common in the surveyed companies, and project success appears to be independent of the adopted arrangement. The organic behavior of the small and medium companies is able to overcome the potential deficiencies of the functional structures.

This research was designed for Brazilian SMEs in the PCAD and MD industries and revealed patterns of critical 
success factors particular to those industries. The results are limited to these two industries but could be applied to other companies with the same profile. The framework used in this study may be applicable to investigate the same issues in other SME in technology based industries.

Concerning the research methodology used, this research was able to reveal the critical factors in NPD management. Compared with previous research methodologies that have identified critical success factors by examining causal relationships, the present research provides implications for the allocation of future efforts. Future works could analyze, in greater depth, the degree of influence of the market and its dynamics, the regulatory environment, the adoption and relevance of specific management practices in NPD, such as gates review and characteristics of the project team leader. It seems also promising to analyze the specificities of NPD management geared either towards the product or the development process.

One of the limitations in this study is the fact that it was carried out with a small sample of PCAD and MD companies. Additionally, some practices related to NPD management, such as financial evaluation along the development process, and others were not integrated into the scope of the proposed conceptual model. Future works can replicate the methodology adopted in other industries, so that knowledge of NPD management in SMEs can be better explored.

\section{References}

ATUAHENE-GIMA, K. Differential potency of factors affecting innovation performance in manufacturing and services Companies in Australia. Journal of Product Innovation Management, v. 13, n. 1, p. 35-52, 1996. http:// dx.doi.org/10.1016/0737-6782(95)00090-9

BELL, M.; PAVITT, K. Technological Accumulation and Industrial Growth: contrasts between developed and developing countries. Industrial and Corporate Change, v. 2, p. 157-210, 1993. http://dx.doi.org/10.1093/icc/2.1.157

BERRY, M. M. J.; TAGGART, J. M. Combining technology and corporate strategy in small high tech firms. Research Policy, v. 26, n. 7, p. 883-895, 1998. http://dx.doi. org/10.1016/S0048-7333(97)00064-4

BROWN, S. L.; EISENHARDT, K. M. Product development: past research, present findings, and future-directions. Academy of Management Review, v. 20, n. 2, p. 343378, 1995.

CLARK, K. B.; WHEELWRIGHT, S. C. Managing new product and process development: text and cases. New York: The Free Press, 1993.
CLARK, K. B.; FUJimOTO, T. Product development performance: strategy, organization and management in the world auto industry. Boston: HBS Press, 1991.

COOPER, R. G.; KLEINSCHIMIDT, E. J. New products: what separates winner form losers. Journal of Product Innovation Management, v. 4, n. 3, p. 169-184, 1987. http://dx.doi.org/10.1016/0737-6782(87)90002-6

COOPER, R. G.; KLEINSCHIMIDT, E. J. Determinants of timeless in product development. Journal of Product Innovation Management, v. 11, p. 381-396, 1994. http:// dx.doi.org/10.1016/0737-6782(94)90028-0

COOPER, R. G.; KLEINSCHIMIDT, E. J. Benchmarking the firm's critical success factors in New Product Development. Journal of Product Innovation Management, v. 12, p. 374-391, 1995. http://dx.doi.org/10.1016/07376782(95)00059-3

COOPER, R. G.; EDGETT, S. J.; KLEINSCHMIDT, E. J. Benchmarking best NPD practices-I. Research Technology Management, v. 47, n. 1, p. 31-43, 2004a.

COOPER, R. G.; EDGETT, S. J.; KLEINSCHMIDT, E. J. Benchmarking best NPD practices-II. Research Technology Management, v. 47, n. 3, p. 50-59, 2004 b.

COOPER, R. G.; EDGETT, S. J.; KLEINSCHMIDT, E. J. Benchmarking best NPD practices-III. Research Technology Management, v. 47, n. 6, p. 43-55, 2004c.

ERNST, H. Success factors of new product development: a review of the empirical literature. International Journal of Management Review, v. 4, n. 1, p. 1-40, 2002. http:// dx.doi.org/10.1111/1468-2370.00075

GARCIA, R.; CALANTONE, R. A critical look at technological innovation typology and innovativeness terminology: a literature review. Journal of Product Innovation Management, v. 19, n. 2, p. 110-132, 2002. http://dx.doi. org/10.1016/S0737-6782(01)00132-1

GRIFFIN, A. PDMA Research on new product development practices: Updating trends and benchmarking best practices. Journal of Product Innovation Management, v. 14, p. 429-458, 1997. http://dx.doi.org/10.1016/S07376782(97)00061-1

HAIR, J. F. et al. Multivariate data analysis. 5th ed. New Jersey: Prentice-Hall, 1998.

HAQUE, B.; KULWANT, S. P.; BARSON, R. J. Analyzing Organizational Issues in Concurrent New Product Development. International Journal of Productions Economics, v. 67, p. 169-182, 2000. http://dx.doi. org/10.1016/S0925-5273(00)00017-7

HART, S. Dimensions of success in new product development: an exploratory investigation. Journal of Marketing Management, v. 9, p. 23-41, 1993. http://dx.doi.org/10.10 80/0267257X.1993.9964215 
KAHN, K. B.; BARCZAK, G.; MOSS, R. Perspective: Establishing an NPD best practices Framework. Journal of Product Innovation Management, v. 23, p. 106-116, 2006. http://dx.doi.org/10.1111/j.1540-5885.2006.00186.x

KIM, Y.; BYUNGWOOK, M.; JONGSEOK, C. The Roles of R\&D team leaders in Korea: a contingent approach. R\&D Management, v. 29, n. 2, p. 153-166, 1999. http://dx.doi. org/10.1111/1467-9310.00126

LANGERAK, F.; HULTINK, E. J.; ROBBEN, H. S. J. The impact of market orientation, product advantage, and launch proficiency on new product performance and organizational performance. Journal of Product Innovation Management, v. 21, n. 2, p. 79-94, 2004. http:// dx.doi.org/10.1111/j.0737-6782.2004.00059.x

LARSON, E. W.; GOBELLI, D. H. Organizing for product development projects. Journal of Product Innovation Management, v. 5, n. 3, p. 180-190, 1988. http://dx.doi. org/10.1016/0737-6782(88)90021-5

LEDWITH, A.; O'DWYER, M. Market Orientation, NPD Performance, and Organizational Performance in Small Firms. Journal of Product Innovation Management, v. 26, n. 6, p. 652-661, 2009. http://dx.doi.org/10.1111/ j.1540-5885.2009.00690.x

LEE, J.; LEE J.; SOUDER, W. E. Differences of organizational characteristics in new product development cross-cultural comparison of Korea and US. Technovation, v. 20, p. 497-508, 2000. http://dx.doi.org/10.1016/S01664972(99)00169-8

MARCH-CHORDA, I.; GUNASEKARAN, A.; BEGOÑA, L. Product development process in Spanish SMEs: an empirical research. Technovation, v. 22, n. 5, p. 301-312, 2002. http:// dx.doi.org/10.1016/S0166-4972(01)00021-9

MONTOYA-WEISS, M.; CALANTONE, R. Determinants of new product performance: a review and meta-analysis. Journal of Product Innovation Management, v. 11, p. 397-417, 1994. http://dx.doi.org/10.1016/07376782(94)90029-9

MOSEY, S. Understanding New-to-Market Product Development in SMEs. International Journal of Operations \& Production Management, v. 25, n. 2, p. 11430, 2005. http://dx.doi.org/10.1108/01443570510576994

ORGANIZATION FOR COOPERATION AND DEVELOPMENT ECONOMIC - OCDE. Oslo Manual: proposed guidelines for collecting and interpreting technological innovation data. Washington: Organization for Economic Co-operation and Development: Statistical Office of the European Communities, 1997.
POOLTON, J.; BARCKLAY, I. New Product Development From Past Research to Future Applications. Industrial Marketing Management, v. 27, p. 197-212, 1998. http:// dx.doi.org/10.1016/S0019-8501(97)00047-3

RIEK, R. F. From Experience: Capturing hard-won lessons in checklists. Journal of Product Innovation Management, v. 18, p. 301-313, 2001. http://dx.doi.org/10.1016/S07376782(01)00100-X

SCHWEIGER, D. M.; ATAMER, T.; CALORI, R. Transactional project teams and networks: making the multinational organization more effective. Journal of World Business, v. 139, p. 1-14, 2003.

SCOTT, G. M. Critical Technology Management Issues of New Product Development in High Tech Companies. Journal of Product Innovation Management, v. 17, p. 57-77, 2000. http://dx.doi.org/10.1016/S0737-6782(99)00012-0

SONG, X. M.; SOUDER, W.; DYER, B. A causal model for studying the impact of skills, synergy, and design sensitivity on new product performance. Journal of Product Innovation Management, v. 14, n. 2, p. 88-101, 1997. http://dx.doi.org/10.1016/S0737-6782(96)00076-8

SONG, X. M.; NOH, J. Best new product development and management practices in the Korean high-tech industry. Industrial Marketing Management, v. 35, p. 262-278, 2006. http://dx.doi.org/10.1016/j.indmarman.2005.04.007

SOUDER, W. E.; BUISSON, D.; GARRET, T. Success through customer-driven new product development: a comparison of US and New Zealand small entrepreneurial high technology Companies. Journal of Product Innovation Management, v. 14, p. 459-472, 1997. http://dx.doi.org/10.1016/S07376782(97)00064-7

THIEME, R. J.; SONG, X. M.; SHIN, G. C. Project management characteristics and new product survival. Journal of Product Innovation Management, v. 20, n. 2, p. 104-119, 2003. http://dx.doi.org/10.1111/15405885.2002004

VERHEES, F. J. H. M.; MEULENBERG, M. T. G. Innovativeness, Produce Innovation and Performance in Small Firms. Journal of Small Business Management, v. 42, n. 2, p. 134-54, 2004. http://dx.doi.org/10.1111/ j.1540-627X.2004.00102.X

YAP, C. M.; SOUDER, W. E. Factors Influencing New Product Success and Failure in Small Entrepreneurial HighTechnology Electronic Companies. Journal of Product Innovation Management, v. 11, p. 418-432, 1994. http:// dx.doi.org/10.1016/0737-6782(94)90030-2 